\title{
PRINSIP MORAL SEBAGAI KLAIM PADA HAK CIPTA DAN HAK UNTUK DILUPAKAN (RIGHT TO BE FORGOTTEN)
}

\author{
Bambang Pratama \\ email: bptama@gmail.com
}

\begin{abstract}
In this current digital era, the issue how to protect private-personal electronic or digital data creates the need for the recognition of a new legal right (right to be forgotten/right to delete). Legal recognition of this right must be balanced with the duty of internet service provider to control and monitor the dispersion of negative content (resulting in copyright infringements, infringements of the sanctity of personal-private data, etc.). With the amendment of Law No. 11 of 2008 re. Electronic Information and Transactions, it becomes appropriate to discuss the right to be forgotten in terms of moral principles. The existence of this moral right is reflected in the legal protection of copyright as well as protection of private-personal data. The main argument here is that moral principle or right as part of natural law should be used to explain the existence and importance of the right to be forgotten.
\end{abstract}

Keywords: copyright. personal right. data privacy. moral principle.

\begin{abstract}
Abstrak
Di era digital sekarang ini, persoalan bagaimana melindungi data memunculkan konsep hukum baru yaitu hak untuk dilupakan (right to be forgotten/right to delete). Pengaturan tentang hak untuk dilupakan perlu diiringi pembebanan kewajiban kepada penyelenggara sistem elektronik untuk membuat mekanisme kontrol terhadap penyebaran konten negatif (pelanggaran hak cipta, data pribadi atau lainnya). Dengan dimasukkannya ketentuan tentang hak untuk dilupakan ke dalam amandemen Undang-undang No. 11 Tahun 2008 tentang Informasi dan Transaksi Elektronik, maka relevan membahas hak untuk dilupakan ini sebagai prinsip atau hak moral yang juga tercermin dalam perlindungan hak cipta maupun perlindungan atas data pribadi. Argumen utama di sini adalah bahwa adanya prinsip atau hak moral sebagai bagian hukum kodrat menjadi titik tolak untuk menjelaskan adanya hak untuk dilupakan.
\end{abstract}

Kata Kunci: hak cipta. hak pribadi. data pribadi. prinsip moral.

\section{Pengantar}

Hak cipta merupakan salah satu bentuk dari kekayaan intelektual ${ }^{1}$ yang sifatnya unik dibandingkan dengan jenis kekayaan intelektual lainnya. Ada tiga Asas hukum/prinsip hukum yang melekat pada hak cipta, yaitu: prinsip moral, prinsip ekonomi dan prinsip derivasi. Hak cipta mewarisi prinsip hukum benda

1 Dengan dikeluarkannya Peraturan Presiden No. 44 Tahun 2015 tentang Kementerian Hukum dan Hak Asasi Manusia. Ketentuan pasal 26 menyatakan bahwa nomenklatur Hak Kekayaan Intelektual (intellectual property rights) diganti dengan Kekayaan Intelektual (intellectual property). Alasan ini didasarkan pada pemikiran bahwa frasa 'hak' menunjuk pada perlindungan hukum kekayaan intelektual. Jadi penyebutan kata hak bisa digunakan setelah kekayaan intelektual terdaftar di Kementerian Hukum dan HAM. 
yaitu hak personalitas, yang kemudian ditransformasikan menjadi hak moral. Dalam sejarahnya, yang menarik dari prinsip ini adalah prinsip yang hanya dikenal di dalam keluarga sistem hukum Eropa Kontinental. Sedangkan prinsip ekonomi dan prinsip derivasi lebih banyak dikenal di dalam keluarga sistem hukum AngloSaxon.

Prinsip moral menjadi salah satu karakteristik hak kebendaan yang melekat pada hak cipta di berbagai negara. Indonesia sebagai salah satu negara penganut sistem hukum Eropa Kontinental tentunya harus mengatur tentang hal ini secara an sich. Mengingat pentingnya prinsip moral sebagai manifestasi dari hak kebendaan maka ada konsensus internasional yang mengatur tentang hal ini terkait hak cipta, yaitu: Bern Convention, Geneva Convention, Paris Convention, TRIPS dan sebagainya. Kesemua konvensi-konvensi internasional di atas pada prinsipnya memempengaruhi aturan hukum pada hak cipta.

Prinsip moral merupakan postulat dari natural right yang merupakan hak asasi manusia. Prinsip moral dalam perkembangannya menjadi dasar berbagai prinsip hukum lainnya, seperti hak privasi. Di era digital saat ini, prinsip pada hak privasi kemudian diturunkan lagi menjadi hak atas data privasi. Oleh sebab itu, prinsip moral ini menarik untuk dibahas lebih mendalam. Pasalnya, dimensi hukum yang muncul dari prinsip tidak hanya ada pada rezim hukum hak cipta saja. Pengadopsian prinsip moral pada perlindungan privasi boleh jadi disebabkan atas alasan bahwa prinsip-prinsip dari hak cipta dianggap sudah mapan (established). Salah satu contoh penerapan prinsip ini misalnya ketika pengalaman hidup seseorang tidak bisa diberikan kepada ahli warisnya, tetapi diwarisi oleh ahli waris ketika seseorang meninggal ${ }^{2}$ atau muncul pertanyaan kepemilikan atas mayat seseorang yang sudah meninggal? Pertanyaan-pertanyaan tersebut di atas pada akhirnya memunculkan pertanyaan turunan lainnya, yaitu berapa lama jangka waktu perlindungan hak ini? Jawaban atas pertanyaan ini seringkali menggunakan konsep perlindungan pada hak cipta sebagai justifikasi. Atas dasar tersebut di atas, maka relasi dari klaim natural right dengan hak milik dan hak kekayaan intelektual dapat dipetakan pada gambar di bawah ini.

2 Prue Vines, The Sacred and the Profane: The Role of Property Concepts in Disputes about Postmortem Examination. 242-244 (Sydney Law Review, Vol. 29:235). 


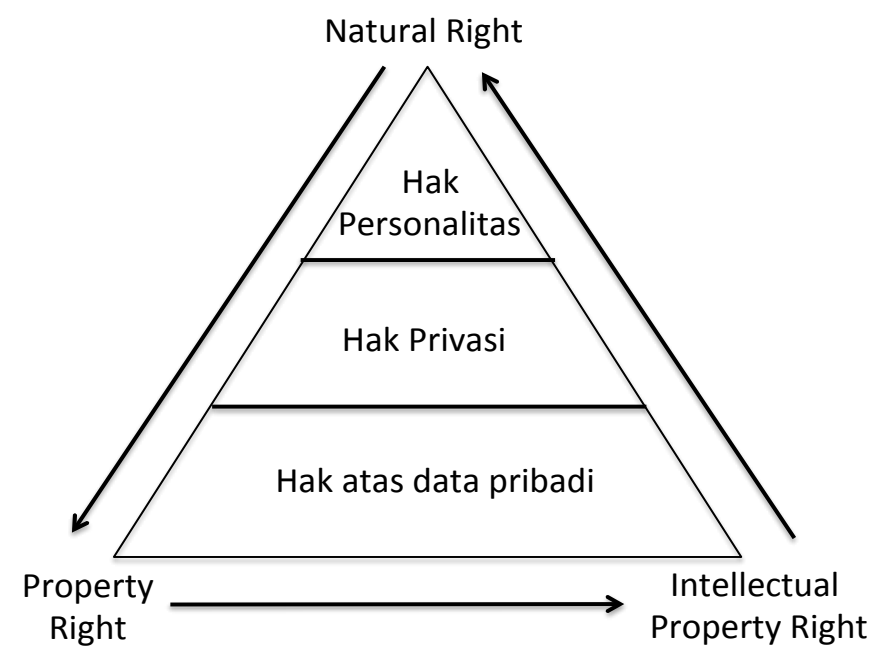

Gambar 1. Relasi Hak Individual

Gambar di atas menunjukkan bahwa klaim atas hak-hak individual berhubungan erat dengan prinsip hukum benda dan prinsip hukum kekayaan intelektual. Rezim hukum kekayaan intelektual yang mengakomodir ketentuan tentang natural right ini adalah hak cipta. Pada hukum hak cipta, natural right diturunkan menjadi prinsip moral yang kemudian dirumuskan normanya menjadi hak hukum berupa hak moral. Adanya transformasi hak menjadi hak moral menjadi penting diketahui, pasalnya hak moral ini menjadi landasan pijak hubungan hukum antara orang (individu) dengan benda, dan penggunaan benda oleh pemilik dengan orang lain. Dengan menggunakan gambar di atas, maka alas hak terhadap data pribadi adalah hak kebendaan yang bisa dipersamakan seperti hak kekayaan intelektual khususnya hak cipta.

Berangkat dari argumentasi di atas, maka kedudukan prinsip moral pada hak cipta tidak bisa dipandang sebelah mata, karena sedikit banyaknya menggambarkan konsep kepemilikan antara orang (individu) dengan bendanya sebagai hak milik. Pentingnya pijakan hukum untuk dijadikan argumentasi hak milik ini menjadi penting untuk dijelaskan karena prinsip hak milik yang dianut oleh Indonesia menggunakan sistem tertutup, ${ }^{3}$ yang mana tata cara mendapatkan hak milik harus berdasarkan undang-undang. Ini berarti, tanpa penetapan undangundang maka suatu objek hukum tidak bisa diklaim kepemilikannya. Padahal

3 Sri Soedewi Masjchoen Sofwan, Hukum Perdata: Hukum Benda, Liberty Yogyakarta, Cetakan kelima, 2000, hlm., 15. 
obyek hukum tersebut adalah bagian dari hak asasi manusia, yaitu hak pribadi dan data pribadi.

Salah satu contoh sengketa terkait hak pribadi ini adalah kasus Film Soekarno yang dituntut oleh Rachmawati Soekarno Puteri terhadap PT. Multivision. Ini adalah contoh klaim terhadap informasi pribadi berupa pengalaman hidup seseorang. Tuntutan ini diajukan oleh anak Soekarno terhadap PT. Multivision karena film yang dibuatnya tidak sesuai dengan kehidupan pribadi Soekarno. ${ }^{4}$ Meski putusan pengadilan pada kasus ini mengalahkan Rachmawati, akan tetapi kasus ini memberi pelajaran bahwa perlindungan tentang kehidupan pribadi seseorang seharusnya bisa diklaim sebagai bentuk dari hak personalitas pemiliknya.

Klaim atas kehidupan pribadi seseorang pertama kali muncul pada kasus Melvin vs. Reid pada tahun 1931 di California, Amerika Serikat. ${ }^{5}$ Gabriele Darley Melvin adalah mantan pelacur yang membunuh suaminya. Kisah kehidupan Melvin kemudian dibuat film dengan judul The Red Kimono oleh Dorothy Davenport Reid. Melvin merasa keberatan kisah hidupnya dibuat film, kemudian menuntut Reid untuk menarik film tersebut dengan klaim hak personalitas. Putusan pengadilan pada waktu itu memutuskan bahwa ketentuan tentang hak pribadi diakui oleh hukum Amerika melalui distrik California. ${ }^{6}$ Salah satu alasan yang digunakan hakim pada waktu itu adalah right to be let alone.

Konsep right to be let alone ini kemudian dikembangkan pada tahun 2006 di Spanyol. Pengembangan dari hak personalitas ini dikenal dengan sebutan right to be forgotten (selanjutnya disingkat RBF). Kemunculan konsep RBF di Uni Eropa adalah untuk respon dari pengguna Internet (netizen) agar terbebas dari stigma masa lalu. ${ }^{7}$ Titik tolak kemunculan RBF adalah pada tuntutan yang diajukan oleh Mario Costeja González terhadap Google.Inc yang diajukan kepada pengadilan Uni Eropa/the Court of Justice of the European Union pada bulan Mei 2014 yang menuntut dihapuskannya informasi tentang dirinya yang bangkrut di masa lalu.

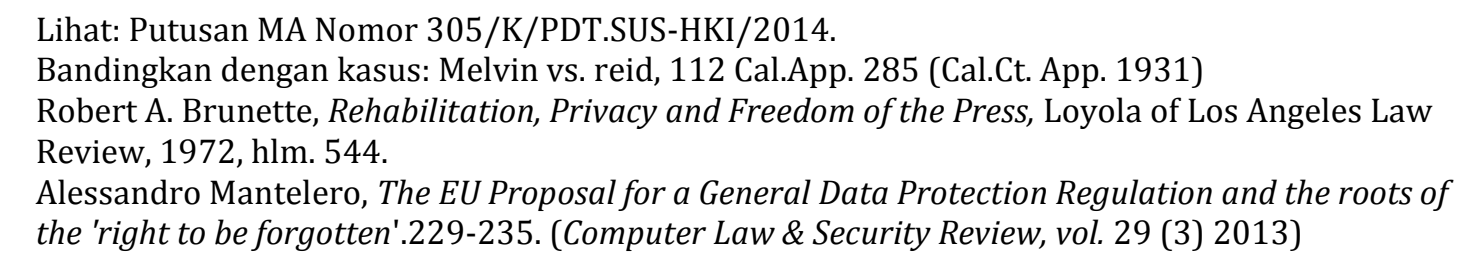


Dengan dimenangkannya tuntutan González, maka konsep RBF diterapkan di seluruh Uni Eropa.

Penjelasan di atas secara empiris menunjukkan bahwa kajian tentang prinsip moral adalah kajian yang menarik untuk dibahas, tidak hanya dalam perspektif hak cipta saja. Meski hak cipta tidak bisa dikaitkan secara langsung terhadap perlindungan hak pribadi seseorang, tetapi prinsip moral yang melekat pada hak cipta adalah landasan dari hak kepribadian seseorang sebagai pencipta. Dalam konstruksi perlindungan hukum tentang prinsip moral, hukum menjadikannya sebagai obyek dari konsep kebendaan. Meski pada mulanya prinsip ini berangkat dari natural right. Ini menunjukkan pula bahwa pada prinsip ini ada pengaruh pemikiran utilitarian yang mengukurnya dengan ukuran ekonomi. Pandangan utilitarian ini dikenal dengan sebutan prinsip ekonomi yang kemudian diturunkan menjadi hak ekonomi pada hak cipta. Bertolak dari kontestasi prinsip moral pada hak cipta dan hak pribadi, maka pertanyaan induk yang dapat dirumuskan dari penelitian ini adalah bagaimana pengadopsian prinsip moral pada hak cipta dan hak untuk dilupakan? Pengaturan hak untuk dilupakan ini merupakan norma yang baru ditetapkan pada revisi Undang-undang No. 11 Tahun 2008 tentang Informasi dan Transaksi Elektronik (selanjutnya disingkat UU-ITE).

Untuk menjawab pertanyaan di atas, penelitian ini menggunakan metode penelitian yuridis normatif, dengan mengkaji bahan hukum primer dan bahan hukum sekunder sebagaimana diajarkan oleh Soerjono Soekanto. ${ }^{8}$ Untuk memenuhi karakteristik keilmiahan dari tulisan hukum maka penelitian ini tentunya berusaha menangkap makna dari ketentuan yuridis, berupa asas hukum dan teori hukum. ${ }^{9}$ Bahan-bahan hukum yang digunakan dalam penelitian ini tentunya tidak terbatas pada peraturan perundang-undangan semata, tetapi mencakup konten yang terkait hukum baik yang berasal dari proses yudisial

Soerjono Soekanto, Pengantar Penelitian Hukum, UI-Press, 1984, hlm., 47-48.

Adilah Abd. Razak, Understanding Legal Research, Integration and Dissemination, Universiti Putra Malaysia, 2009, hlm., 20. 
ataupun yang tidak melalui proses yudisial, seperti karya ilmiah dan buku. ${ }^{10}$ Konsekuensi dari pemilihan metode di atas adalah penelitian ini terbatas (scope of research) pada dua aspek, yaitu hak cipta dan hak pribadi terkait perlindungan data pribadi yang diturunkan menjadi hak untuk dilupakan (right to be forgotten). Keterbatasan penelitian ini (research limitation) tidak mampu menjelaskan latar belakang penyusunan peraturan tentang hak cipta dan perlindungan data pribadi. Untuk mengantisipasi hal ini maka pendekatan yang digunakan dalam penelitian ini menggunakan pendekatan analitis dan konseptual.

\section{Perlindungan atas Data Pribadi}

Secara yuridis, hak pribadi bisa saja dikaitkan dengan kehormatan seseorang. 11 Solove mengatakan, ada perbedaan antara keduanya. Pada perlindungan terhadap kehormatan kerugian yang dialami berada pada reputasi seseorang. Sedangkan pada privasi kerugian yang dialami terletak pada perasaan, yang mana memiliki dimensi psikologis. ${ }^{12}$ Jika saat ini belum ada aturan hukum yang mengaturnya, maka hak pribadi dan hak privasi di Indonesia keduanya digabung menjadi satu.

Solove juga mengatakan bahwa ada kesulitan meletakkan argumen yuridis terhadap perasaan seseorang. Oleh sebab itu, ia membuat enam tipe dari privasi, yaitu: (1) hak untuk menyendiri; (2) hak untuk menutup diri dari orang lain; (3) hak untuk menutup hal-hal tertentu dari orang lain; (4) hak untuk mengendalikan informasi pribadi; (5) hak untuk melindungi kepribadian; dan (6) hak untuk berhubungan dengan orang lain. ${ }^{13}$

Perlu disampaikan bahwa konsep privasi adalah konsep yang berasal dari Barat yang kemudian ditetapkan melalui berbagai konvensi internasional. Oleh sebab itu, argumentasinya akan melulu berujung pada hak, yang mana gagasan ini bertolak dari gagasan hak asasi sosial ekonomi dan kultural yang bertumpu pada suatu filsafat individualistik. Gijssels \& Hoecke mengatakan, hak individu tidak

\footnotetext{
10 Soetandyo Wignjosoebroto, Penelitian Hukum dan Hakikatnya Sebagai Penelitian Ilmiah, dalam Metode Penelitian Hukum Konstelasi dan Refleksi, Editor: Sulistyowati Irianto \& Shidarta, Yayasan Obor, Jakarta, 2011, hlm 90-91.

11 Lihat pasal 310 dan pasal 311 KUH Pidana tentang delik terhadap kehormatan.

12 Daniel J. Solove. Conceptualizing Privacy, California Law Review, 2002, hlm 1101.

13 Id. hlm., 1092.
} 
meletakkan tekanan pada warga masyarakat sebagai anggota dari suatu kelas, kelompok, keyakinan dan perbedaan lainnya maka harus ada koreksi dari negara melalui suatu kebijakan ${ }^{14}$ agar tercipta keseimbangan dalam masyarakat.

Pendapat Gijssels \& Hoecke ini memang beralasan, karena dalam perkembangannya privasi diperluas pengertiannya, yaitu terkait informasi pribadi, otonomi, ruang fisik dan hak kebendaan. ${ }^{15}$ Klaim-klaim ini sangat kental bernuansa individualistik yang berkembang di Barat. Berikut ini adalah pembagian empat lapisan dari hak pribadi menurut Mills.

Taksonomi lapisan privasi yang dikemukakan oleh Mills mungkin terkesan tidak relevan ketika menempatkan hak kebendaan di dalamnya, dibandingkan dengan komponen otonomi, informasi pribadi dan ruang fisik. Tetapi argumentasi Mills dibangun berdasarkan tesis dari Epstein dan Gaus tentang hak milik yang berkembang di barat, yaitu: (1) property is about division of resources, dan (2) the property rights equilibrium is mutually beneficial. ${ }^{16}$

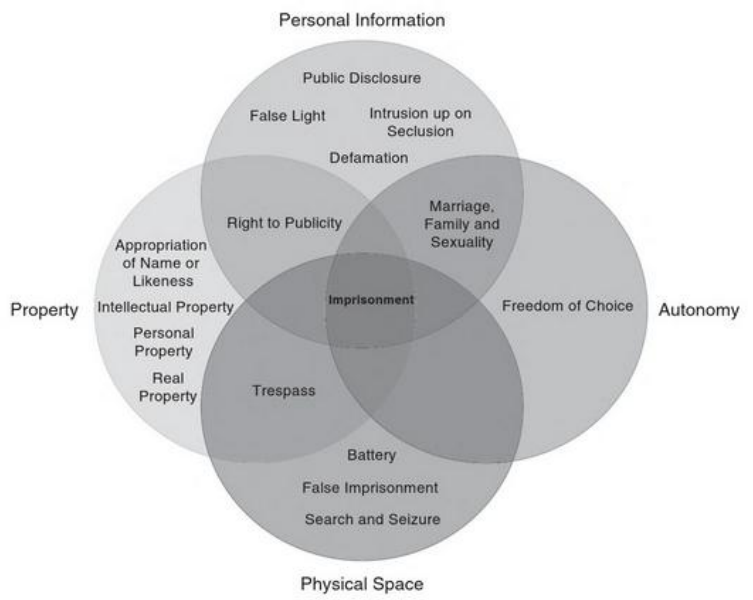

Gambar 2. Empat Lapisan Privasi

Tentang hak milik, Epstein mengatakan secara historis ada konvergensi antara penganut sistem hukum Eropa Kontinental dengan Anglo-Saxon dalam hal

14 Jan Gijssels \& Mark van Hoecke. Wat is rechtsteorie? (1982). Diterjemahkan oleh B. Arief Sidharta. (2001). Apakah Teori Hukum Itu? Laboratorium Hukum, Fakultas Hukum, Universitas Katolik Parahyangan, 2001, hlm., 34.

15 Jon. L. Mills. Privacy The Lost Right. Oxford University Press. New York, 2008, hlm., 14.

16 Gerald Gaus. Property and Ownership, Edited by: David Estlund, Oxford University Press, 2012, hlm., 123-124. 
penguasaan benda. ${ }^{17}$ Oleh sebab itu pada intinya hak yang melekat pada suatu hak milik adalah pemberian ijin untuk menggunakan benda dan mendapatkan kenikmatan atas suatu benda. ${ }^{18}$ Dengan demikian konsep kebebasan (liberty) niscaya melekat pada suatu hak. Epstein juga mengatakan bahwa argumentasinya akan sesuai dengan berbagai versi teori hukum yang ada. Menurutnya, pada intinya semua teori hukum mengarah pada pendapat yang sama. Dalam konsep hak milik juga akan ditemukan pelanggaran (tort) jika ada orang yang melanggar hak milik orang lain. Konsep inilah yang pada mulanya dikenal sebagai konsensus ${ }^{19}$ di masyarakat yang kemudian ditetapkan menjadi norma hukum oleh pemerintah. ${ }^{20}$

Menurut Rosen, semua pengetahuan, mencakup kepribadian seseorang adalah informasi yang menyangkut privasi. 21 Jika proposisi Rosen dikorespondensikan dengan hukum Indonesia maka berbagai informasi terkait data pribadi setidaknya tersebar pada 22 undang-undang khusus (lex specialist) ${ }^{22}$ yang notabene berkaitan dengan informasi pribadi. Terkait informasi, maka bentuk dari informasi ini tidak terbatas pada bentuk fisik pada umumnya, tetapi bisa berbentuk elektronik, yang mana digolongkan ke dalam lingkup hukum siber. Dalam perspektif UU-ITE, pada Seminar Urgensi Perlindungan Data Pribadi tanggal 9 Januari 2015, Abu Bakar Munir²3 (selanjutnya disingkat ABM) di Universitas Bina Nusantara menyampaikan bahwa UU-ITE di Indonesia tidak lazim karena tidak ada satu negarapun di dunia ini yang di dalam pengaturan UU-ITE mencantumkan sanksi pidana karena UU-ITE sifatnya privat bukan publik. ABM juga berpendapat

17 Argumentasi yang dibangun oleh Epstein bertolak dari nilai-nilai moralitas yang terdapat pada konstitusi, yang mana hal ini juga sesuai dengan argumentasi hukum yang dikemukakan oleh Ronald Dworkin. Lihat: Suzanna Sherry. Property is The New Privacy, The Coming Constitutional Revolution, Harvard Law Review. 2015, hlm. 1435.

18 Richard A. Epstein. The 'Necessary' History of Property and Liberty, University of Chicago. 2003, hlm., 11.

19 Richard A. Epstein. Property Right, State of Nature Theory, and Environmental Protection. Journal of Law and Liberty. New York University. 2009, hlm. 3.

20 Richard A. Epstein. The Path to The T.J. Hooper: The Theory and History of Custom in The Law of Torts, Chicago Law Review. 1991, hlm. 11.

21 Robert C. Post, Three Concepts of Privacy. 2088. Faculty Scholarship Series, Yale Law School, 2001, hlm 185.

22 Bambang Pratama, ICT Law Framework Toward ASEAN Economy Community, Unisbank Semarang, 2013.

23 Abu Bakar Munir merupakan konsultan hukum bagi pemerintah dalam pembuatan UU-ITE tahun 2008. ABM juga menjadi konsultan bagi pemerintah Malaysia. Saat ini menjadi konsultan pemerintah Mesir dalam menyusun undang-undang perlindungan data pribadi. 
bahwa saat ini di Indonesia belum ada peneliti yang adekuat dan fokus meneliti bidang hukum siber khususnya perlindungan data pribadi. Dari sudut pandang yuridis, hingga saat ini belum ada aturan khusus yang benar-benar mengatur tentang perlindungan data pribadi. Alhasil, kondisi saat ini pengaturan tentang perlindungan data pribadi tersebar secara parsial di berbagai undang-undang.

\section{Prinsip Moral pada Hak Cipta}

Berbeda dengan perlindungan hak pribadi, pada hak cipta konsep kepribadian individu diwariskan ke dalam prinsip moral pada hak cipta. Berdasarkan penjelasan di atas, ada indikasi perbedaan konsep pada negara penganut sistem hukum Eropa Kontinental dengan negara Anglo-Saxon, yang mana pada negara Anglo-Saxon konsep ekonomi dilekatkan ke dalam konsep moralitas untuk mengklaim menjadi hak milik.

Konsep hak cipta secara historis menurut Goldstein berasal dari dua sistem hukum yang berbeda (civil law dan common law). ${ }^{24}$ Kemudian pasca konvensi Bern di Roma pada tahun 1928 perbedaan dua konsep hukum ini diunifikasi, di sinilah unifikasi dua konsep hukum menjadi satu pada hak cipta, yaitu prinsip moral dan prinsip ekonomi. Dalam beberapa essay klasik, aturan hukum tentang hak cipta dalam keluarga sistem hukum Eropa Kontinental dikenal dengan sebutan auterswet (Belanda), droid d'auteur (Perancis), Urheberrecht (Jerman) dan diritto d'autore (Italia). Sedangkan dari essay yang berasal dari Anglo-Saxon, ditemukan bahwa peristilahan yang kerap muncul adalah right-to-copy (hak hukum untuk melakukan perbanyakan). ${ }^{25}$

Bertolak dari argumentasi Goldstein tentang prinsip hukum hak cipta di dua keluarga sistem hukum yang berbeda juga mengacu pada dua konsep yang berbeda. Pada keluarga sistem hukum Eropa Kontinental prinsip hukum yang dianutnya adalah prinsip moral yang menginduk pada hak personal (natural right). Sedangkan prinsip ekonomi menginduk pada pemikiran utilitarian atas kemanfaatan ekonomi.

24 Paul Goldstein, International Copyright, Principle. Law, and Practice, Oxford University Press, Madison Avenue, New York, 2001, hlm 5-10.

25 Ernest Miller and Joan Feigenbaum, Taking The Copy Out of Copyright, http://www.cs.yale.edu/ homes/jf/MF.pdf, diakses November 2016. 
Jika dicermati pengaturan tentang prinsip moral pada hak cipta di negaranegara penganut sistem hukum civil law mengatur prinsip moral, menjadikan prinsip ini sebagai prinsip tertinggi dengan menetapkan bahwa prinsip moral adalah hak yang melekat pada pencipta yang tidak dapat dihilangkan. ${ }^{26}$ Pemikiran ini berpijak pada pemikiran Kant dan Hegel tentang moralitas pekerja (labor) untuk mendapatkan hasil atas tenaga yang dikeluarkannya. Alasannya, selain alasan moral, ada alasan kepribadian (personhood) dari pekerja itu. ${ }^{27}$ Perbedaan argumentasi Kant dengan Hegel adalah titik tolak Hegel pada kebebasan individu untuk dapat memanfaatkan hak kebendaan bagi pemiliknya, mencakup hak kepribadian. ${ }^{28}$

Dua negara yang secara tegas mengatur prinsip moral pada hak cipta adalah Perancis dan Jerman. Desbois mengatakan ada 4 jenis hak moral pada hak cipta yang merefleksikan pencipta atas ciptaannya, yaitu: (1) hak untuk mengklaim ciptaannya/hak dicantumkan namanya (right of attribution); (2) hak untuk menolak ciptaannya diubah/menolak modifikasi atas ciptaannya (right of integrity); (3) hak untuk membuka ciptaannya kepada publik/mempublikasikan (right of disclosure); (4) hak untuk menolak ciptaan pasca publikasi (right to withdrawl). ${ }^{29}$

Meski pada awalnya negara-negara Anglo-Saxon tidak mengadopsi prinsip moral ke dalam undang-undang hak ciptanya, tetapi dalam perkembangannya secara perlahan prinsip moral ini diadopsi mereka. Pengakomodasian prinsip moral di negara Anglo-Saxon adalah mentransformasikan prinsip moral menjadi prinsip ekonomi. Salah satu upaya negara penganut sistem hukum common law adalah dengan mengeluarkan undang-undang Visual Artist Right Act, 1990 (VARA Act) sebagai upaya untuk mengakomodasi hak moral ${ }^{30}$ ke dalam undang-undang

26 Thomas F. Cotter, Pragmatism, Economics, and The Droit Moral, North Carolina Law Review, November 1997, http://cyber.law.harvard.edu/metaschool/fisher/integrity/Links/Articles/ cotter.html, diakses: Agustus 2015.

27 Kanu Priya, Intellectual Property and Hegelian Justification, NUJS Law Review, 2008, hlm. 363.

28 Haochen Sun, Designing Journeys to the Social World: Hegel's Theory of Property and His Noble Dream Revisited, Cosmos and History: The Journal of Natural and Social Philosophy. Vol. 6. No. 1, 2010, hlm. 36.

29 Henry Desbois, Le Droit d'Auter En France, (1978). Dalam Mira T. Sundara Rajan, Moral Rights: Principles, Practice and New Technology, Oxford University Press, New York, USA, 2011, hlm 42.

30 Betsy Rosenblatt, Moral Rights Basic, Harvard Law School, March 1998, https://cyber.law.harvard. edu/property/library/moralprimer.html, diakses: Agustus 2015 
hak cipta Amerika Serikat. ${ }^{31} \mathrm{Di}$ sini, Amerika Serikat terlambat meratifikasi konvensi Bern 1928 ini disebabkan karena di sana terjadi perdebatan tentang klasifikasi jenis hak cipta yang dapat ditentukan hak moralnya. ${ }^{32}$

Rigamonti berpendapat, ada tiga justifikasi teori dalam memandang hak moral pada hak cipta, yaitu: (1) monist theory atau teori hak cipta; yang memandang hak moral sebagai hak yang melebur dengan hak ekonomi pada undang-undang hak cipta, (2) right of personality/dualist atau hak natural; yang memandang hak moral sebagai hak naluriah seseorang yang tidak dapat dihilangkan, dan (3) patchwork theory/pendekatan tradisional yang dilakukan oleh negara-negara penganut sistem hukum common law (seperti di Amerika Serikat dan Inggris) dalam mengakomodasikan hak moral ke dalam undang-undang hak cipta di negaranya. Pendekatan ini terkadang menyimpang dari hak moral karena terkadang menggabungkan doktrin hukum lain dalam menafsirkan hak moral. ${ }^{33}$ Tabel di bawah ini adalah jenis-jenis prinsip moral dan prinsip ekonomi pada hak cipta.

Tabel 1. Prinsip Moral dan Prinsip Ekonomi pada Hak Cipta

\begin{tabular}{ll|ll}
\hline \multicolumn{1}{c|}{ Prinsip Moral } & \multicolumn{1}{c}{ Prinsip Ekonomi } \\
\hline 1. Droit de paternite/right of attribution; & 1. & Right of reproduction; \\
2. Droit de au respect de l'integrite de & 2. & Right of distribution; \\
l'oeuvre/respect of the work; & 3. & Rental and lending right; \\
3. Droit de divulgation/right of publication; & 4. $\begin{array}{l}\text { Right of communication to the public } \\
\text { 4. Droit de retrait et de repentir/right to }\end{array}$ & \multicolumn{1}{l}{$\begin{array}{l}\text { making available); } \\
\text { withdraw }\end{array}$} & 5. $\begin{array}{l}\text { Adaptation right; } \\
\text { Droit de suite/resale right }\end{array}$ \\
\hline
\end{tabular}

Dari serangkaian prinsip-prinsip di atas, ada yang menarik dari prinsip droit de suite. Prinsip ini pertama kali diperkenalkan pada tahun 1893 di Perancis dengan peristiwa penjualan lukisan Jean-François Millet yang berjudul Angeléus oleh kolektor yang bernama M.E. Secrétan. Dengan penjualan lukisan tersebut, pemilik lukisan mendapatkan keuntungan yang sangat besar sedangkan Jean-

\footnotetext{
31 VARA Act, 1990 merupakan bentuk ratifikasi konvensi Bern dalam rangka memasukkan perlindungan hak moral ke dalam undang-undang hak cipta di Amerika Serikat. Lihat: Rebecca Tushnet, Naming Rights: Attribution \& Law, Utah Law Review, 2007, hlm. 787.

32 Id. hlm., 793-794.

33 Cyrill P. Rigamonti, The Conceptual Transformation of Moral Rights, The American Journal of Comparative Law, Vol. 55. 2007, hlm., 73-76.
} 
François Millet menderita kemiskinan pasca perang. Dengan alasan ekonomi, kemudian ahli waris Millet menuntut Secrétan untuk mendapat hak ekonomi. Putusan pengadilan pada waktu itu memenangkan tuntutan ahli waris Millet. Atas dasar inilah doktrin droit de suite muncul sebagai upaya upaya mengatasi masalah sosial yang dihadapi oleh pencipta. ${ }^{34}$ Droit de suite merupakan hybrid dari hak moral yang diterapkan pertama kali di Perancis sejak tahun 1920, kemudian dengan dimasukkannya doktrin ini ke dalam Bern Convention tahun 1976. Saat ini setidaknya sudah ada 26 negara yang menerapkan doktrin ini ${ }^{35}$ tetapi sayangnya Indonesia tidak termasuk diantaranya.

Ketentuan di beberapa negara tentang resale rights yang dapat dijelaskan adalah di Jerman yang mengatur tentang resale right pada pasal 26 undang-undang hak ciptanya. Pada hukum hak ciptanya Jerman menyebutkan bahwa the resale right shall be inalienable. The author may not waive his share in advance. ${ }^{36} \mathrm{Hal}$ menarik dari pengaturan resale right di Jeman adalah dimasukkannya ketentuan jumlah nominal uang yang boleh diterima oleh pencipta dari pendapatan royalti resale rights dengan jumlah tidak boleh melebihi dari 12.500 euro. Pengaturan tersebut kemungkinan ditujukan agar tidak terjadi penetapan harga yang tidak realistis dari pencipta sehingga merugikan pemegang hak. Berbeda dengan di Jerman, pengaturan tentang resale rights di Perancis yang mensyaratkan pelaporan kepada menteri tidak lebih dari 24 jam setelah dilakukan penjualan. ${ }^{37}$

Rasionalisasi dari doktrin droit de suite saat ini telah bergeser tidak hanya sebagai remedy social tetapi untuk membangun reputasi dan meningkatkan income pencipta sehingga keduanya dapat meningkatkan value dari suatu ciptaan. ${ }^{38}$ Dengan adanya industri kreatif maka keberadaan droit de suite menjadi penting untuk dapat menjaga hasil ciptaan. Selain itu, prinsip droit de suite juga dapat

34 http://www.assemblee-nationale.fr/12/cri/2005-2006/20060175.asp, diakses Agustus 2015.

35 Michael B. Reddy, The Droit de Suite: Why American Fine Artist Should Have a Right to a Resale Royalty, Layola Marymount University and Loyola Law School. 1995, hlm., 509-510.

36 Lihat Undang-undang Hak Cipta Jerman, Die Übersetzung berücksichtigt die Änderung(en) des Gesetzes durch Artikel 8 des Gesetzes vom 1.10.2013 (BGBl. I S. 3714)

37 Lihat: undang-undang hak cipta Perancis, L122-12, Code la propriété intellectuelle (partie législative, partie réglementaire)

38 Clare McAndrew \& Lorna Dallas-Conte, Implementing Droit de Suite (Artist' Resale Right) in England, The Art Council of England, 2014, hlm., 19. 
menjadi penyeimbang antara manfaat ekonomi yang dimiliki oleh pemegang hak dengan kehormatan pencipta.

Berikut ini adalah tabulasi prinsip moral dan prinsip ekonomi dikaitkan dengan Undang-Undang No. 28 Tahun 2014 tentang Hak Cipta.

\section{Tabel 2. Prinsip Umum Hak Cipta pada Hukum Positif}

\begin{tabular}{|c|c|}
\hline Prinsip Moral & Pengaturan \\
\hline Droit de paternite/right of attribution; & \multirow[b]{2}{*}{ Pasal 5 ayat (1): } \\
\hline Droit de au respect de l'integrite de l'oeuvre/respect of the work & \\
\hline Droit de divulgation/right of publication; & \multirow{3}{*}{$\begin{array}{l}\text { Tidak diatur } \\
\text { Pengaturan }\end{array}$} \\
\hline Droit de retrait et de repentir/right to withdraw & \\
\hline Prinsip Ekonomi & \\
\hline Right of reproduction & \multirow{5}{*}{ Pasal 9} \\
\hline Right of distribution & \\
\hline Rental and lending right & \\
\hline Right of communication to the public (making available) & \\
\hline Adaptation right & \\
\hline Droit de suite/resale right & Tidak diatur \\
\hline
\end{tabular}

Tabel di atas menunjukkan bahwa pengaturan tentang prinsip moral tidak seluruhnya diatur dalam hukum positif. Ini menunjukkan bahwa pembuat undangundang seolah-olah melupakan jati diri dari sistem hukum Eropa Kontinental yang sangat khas melindungi hak individu.

\section{Pengaturan Prinsip Moral Dalam Hukum Indonesia:}

\section{Perlindungan Data Pribadi dan Right to be Forgotten}

Di era digital saat ini, perlindungan atas data pribadi menjadi kebutuhan bagi pengguna Internet. Dengan direvisinya UU-ITE, ketentuan tentang perlindungan data pribadi disempurnakan dengan memasukkan ketentuan tentang RBF. Adapun rumusan tentang perlindungan hak pribadi dan RBF yang tercantum pada pasal 26 ayat (1) dan ayat (2) UU-ITE, adalah sebagai berikut:

Pasal 26

(1) Kecuali ditentukan lain oleh peraturan perundang-undangan, penggunaan setiap informasi melalui media elektronik yang menyangkut data pribadi seseorang harus dilakukan atas persetujuan orang yang bersangkutan. 
(2) Setiap orang yang dilanggar haknya sebagaimana dimaksud pada ayat (1) dapat mengajukan gugatan atas kerugian yang ditimbulkan berdasarkan undang-undang ini. ${ }^{39}$

Dengan diaturnya ketentuan tentang RBF, maka secara umum perlindungan data pribadi bisa dikatakan cukup lengkap pengaturannya. Hanya saja yang terbuka untuk menjadi perdebatan di kemudian hari adalah cakupan dari data pribadi dan alas hak untuk mengklaim data pribadi itu dalam perspektif hak milik yang menggunakan konsep hak kekayaan intelektual.

Perlu diberi catatan bahwa pada ayat (3) dan ayat (4) RUU perubahan UUITE diatur pembebanan kewajiban penyedia jasa elektronik untuk membuat mekanisme penghapusan dokumen elektronik mencakup data pribadi yang dianggap sudah tidak relevan lagi digunakan. Masalah yang muncul dari ketentuan norma ini adalah teknis pelaksanaannya membutuhkan peraturan pemerintah untuk mengaturnya. Padahal jika menggunakan doktrin safe harbor rumusan normanya langsung menunjuk mekanisme sistem elektronik untuk menghapus dokumen pribadi berdasarkan komplain. Dengan menunjuk pada pengaturan PP maka ketentuan ayat (3) dan ayat (4) tidak bisa dikatakan menggunakan doktrin safe harbor karena rumusannya tidak jelas melindungi penyedia sistem elektronik yang diberi kewajiban untuk menjaga konten sistem elektroniknya dari pelanggaran hak cipta dan data pribadi. ${ }^{40}$

Isu RBF menjadi isu global yang pasca putusan kasus González di awal tahun 2014. Perlu di sampaikan bahwa RBF adalah hak turunan dari hak pribadi yang muncul di dunia siber. Ada kemiripan pada RBF dengan delik terhadap kehormatan/pencemaran nama baik (defamation), yaitu tuntutan seseorang atas suatu informasi yang melukai perasaannya. Berikut ini adalah ilustrasi tuntutan RBF dengan tuntutan pencemaran nama baik.

39 Lihat pasal 26 Rancangan Undang-Undang (RUU) Perubahan atas Undang-Undang No. 11 Tahun 2008 tentang Informasi dan Transaksi Elektronik. Perlu diberi catatan, hingga tulisan ini dibuat RUU perubahan UU-ITE sudah disahkan oleh DPR tetapi belum mendapat nomor undangundang.

40 Alfred C. Yen, Internet Service Provider Liability for Subscriber Copyright Infringement, Enterprise Liability, and the First Amendment, The Georgetown Law Journal, Vol. 88. 2000, hlm., 19-21. 


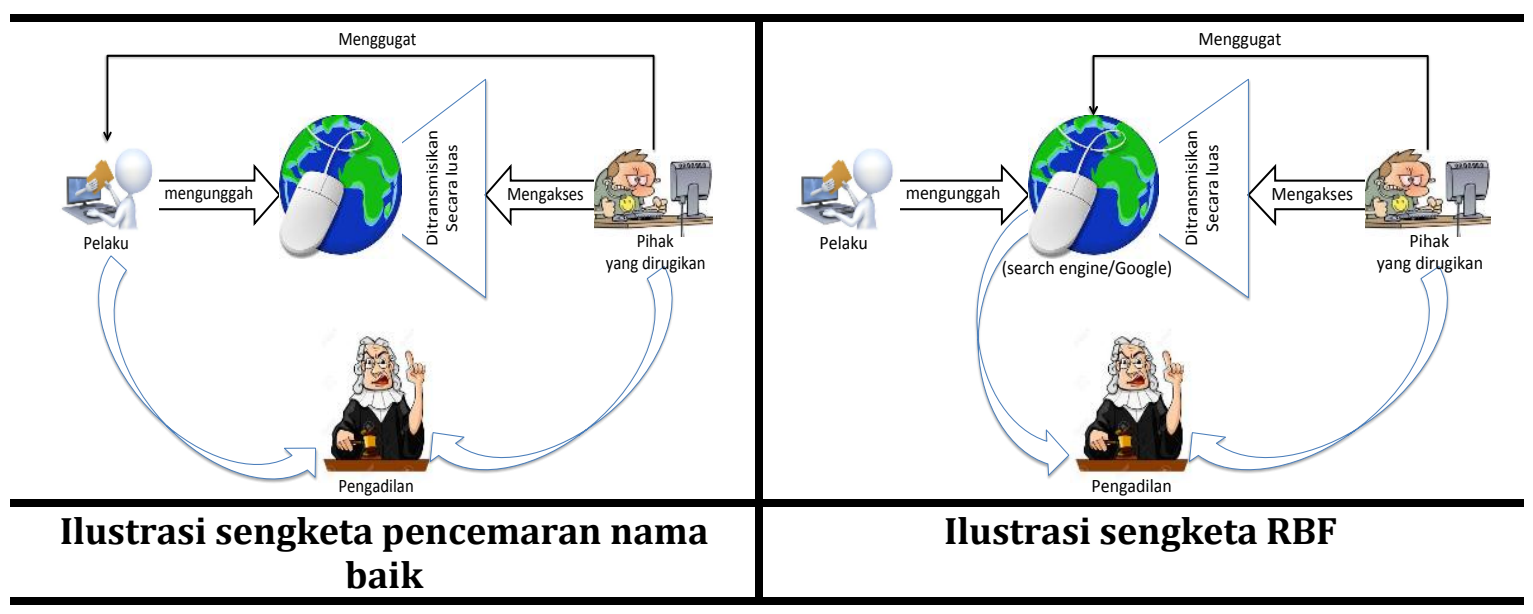

Gambar 3. Komparasi Gugatan Pencemarana Nama Baik dan RBF CBambang Pratama, April 2015.

Dari ilustrasi di atas, terlihat bahwa tuntutan atas RBF bukan ditujukan pada pengunggah (uploader) tetapi ditujukan pada menyedia layanan di Internet. ${ }^{41}$ Secara yuridis formal, pengaturan tentang perlindungan data pribadi selain diatur dalam UU-ITE diatur juga dalam PP No. 82 Tahun 2012 tentang Penyelenggara Sistem dan Transaksi Elektronik (selanjutnya disingkat PP-PSTE).

Penyelenggara sistem elektronik adalah subyek norma dari UU-ITE dan PPPSTE yang dibebankan kewajiban untuk melindungi data pribadi pengguna Internet. Agar perlindungan data pribadi dapat berjalan, undang-undang dan PP mengamanatkan sertifikasi elektronik agar penyelenggaraan sistem elektronik menjalankan sistemnya secara andal dan aman. ${ }^{42}$ Masalahnya, hingga saat ini tidak ada lembaga khusus yang melakukan sertifikasi elektronik ini. Artinya, hingga saat ini pengaturan tentang perlindungan data pribadi tidak berdasarkan aturan hukum yang ada. Kondisi self-regulated yang dialami oleh penyelenggara sistem elektronik ini bukan berarti tanpa standar data treatment. Hingga saat ini mereka bersandar pada ketentuan ISO 27001 tentang Tata Kelola Teknologi Informasi.

Pemerintah sepertinya tidak percaya diri untuk membuat standar sertifikasi ini karena standardisasi tata kelola TIK melalui ISO 27001 berlaku secara internasional. Sedangkan sertifikasi keandalan tentunya akan mirip dengan

41 Penyedia jasa layanan Internet dikenal dengan sebutan penyelenggara sistem elektronik. Lihat definisi pada pasa 1 angka 6 UU-ITE.

42 Lihat UU-ITE dan PP-PSTE tentang sertifikasi penyelenggara sistem elektronik dan sertifikasi keandalan dan kelaikan. 
ketentuan standar nasional Indonesia (SNI). Meski demikian, pengaturan standardisasi ini ditetapkan oleh Badan Standardisasi Nasional dengan mengeluarkan SK No. 95/KEP/BSN/10/2009 tentang penetapan ISO 27001 sebagai acuannya. ${ }^{43}$ Selain itu, ada konsekuensi biaya yang cukup tinggi jika standarisasi ini menggunakan sertifikasi ISO dibandingkan dengan standarisasi nasional buatan Indonesia.

Dalam kaitannya dengan perlindungan data khususnya penerapan RBF, doktrin safe harbor merupakan doktrin yang seharusnya dilekatkan di samping RBF. Alasannya, kewajiban yang di bebankan pada norma RBF harus diimbangi dengan hak bagi penyelenggara sistem elektronik. Doktrin safe harbor adalah doktrin hak cipta yang ditujukan kepada penyelenggara sistem elektronik untuk menjalankan kewajiban memberikan notifikasi kepada pengunggah atas suatu konten yang bermuatan privasi seseorang atau yang bermuatan hak cipta. ${ }^{44}$ Melalui notifikasi ini, penyelenggara memastikan bahwa pengunggah tidak mengunggah konten negatif. Selain itu, penyelenggara juga menyediakan saluran komplain dari pihak yang merasa dirugikan. Berdasarkan komplian atas konten negatif yang diterima, kemudian penyelenggara memiliki hak untuk menutup sementara akses terhadap konten tersebut. Dengan melakukan kewajiban tersebut di atas maka penyelenggara sistem elektronik terbebas dari pertanggungjawaban hukum.

Pembuatan saluran komplain dan penutupan akses oleh penyelenggara sistem elektronik, berarti ada langkah proaktif yang dilakukan oleh penyelenggara untuk memastikan konten yang tersedia oleh layanannya adalah konten positif. Doktrin safe harbor ini digunakan di Amerika Serika pada kasus Viacom International Inc. v. Youtube Inc. \& Google. Inc. Pada kasus ini, Viacom merasa dirugikan karena lebih dari 63.000 film produksinya dipublikasikan tanpa hak oleh

43 Lihat: http://sisni.bsn.go.id/index.php?/sni_main/sni/detail_sni/10233, diakses November 2016.

44 Beberapa putusan landmark cases yang menggunakan argumentasi safe harbor adalah pada kasus (1) Religious Technology Center V. Netcom On-Line Communication Services, Inc. pada tahun 1995; (2) kasus A \& M Records v. Napster pada tahun 2001; (3) kasus Metro-GoldwynMayer Studio Inc. v. Grokster LTD. Pada tahun 2003; dan (4) kasus Viacom International Inc. v. Youtube Inc. \& Google. 2013. 
Youtube melalui media Internet dengan cara video sharing. ${ }^{45}$ Tuntutan yang digunakan Viacom kepada Youtube pada prinsipnya meminta pertanggungjawaban Youtube karena seolah-olah menutup mata atas konten negatif pada layanannya (willful blindness). Padahal Youtube memiliki hak dan kemampuan untuk melakukan kontrol melalui teknologi yang dimilikinya. ${ }^{46}$

Adapun sanggahan yang digunakan oleh Youtube adalah menggunakan doktrin safe harbor pada undang-undang DMCA (Digital Millenium Copyright Act) ${ }^{47}$ yang ditujukan untuk melindungi penyelenggara sistem elektronik. Dengan memberikan notifikasi kepada pengguna, maka pertanggungjawaban sepenuhnya berada pada pengunggah, bukan pada penyelenggara. Adapun kutipan pendapat kongres dalam risalah rapat penyusunan undang-undang DMCA sebagai berikut:

Subsection (c) (3) (A) (iii) requires that the copyright owner or its authorized agent provide the service provider with information reasonably sufficient to permit the service provider to identify and locate the allegedly infringing material. An example of such sufficient information would be a copy or description of the allegedly infringing material and the URL address of the location (web page) which is alleged to contain the infringing material. The goal of this provision is to provide the service provider with adequate information to find and address the allegedly infringing material expeditiously. ${ }^{48}$

Hukum di Amerika Serikat sejak lama telah mengenal doktrin willful blindness yang mana doktrin ini tidak hanya dapat diterapkan pada hak cipta, tetapi dapat juga diterapkan pada bidang kekayaan intelektual lainnya dan data privasi. Willful blindness tidak dapat dikenakan kepada penyedia layanan karena bukan persetujuan berupa kewajiban untuk melakukan pengawasan muatan yang diunggah oleh pengguna. Atas dasar tingginya lalu lintas data maka kongres menetapkan safe harbor sebagai jalan tengah. Adapun ketentuan safe harbor sebagaimana tercantum pada pasal 512 (m) undang-undang hak cipta Amerika Serikat adalah:

45 Youtube adalah salah satu perusahaan milik mesin pencaharian Google. Inc.

46 Kemampuan kontrol teknologi sebagaimana diatur pada pasal $\S 512$ (c) (1) B undang-undang hak cipta Amerika Serikat yang mengatur: the storage is carried out through an automatic technical process for the purpose of making the material available to users of the system or network who, after the material is transmitted as described

47 Undang-undang DMCA adalah undang-undang yang mengatur tentang hak cipta di era digital.

48 Lihat; Risalah rapat penyusunan undang-undang DMCA. 
(m)Protection of Privacy.-Nothing in this section shall be construed to condition the applicability of subsections (a) through (d) on-

(1) a service provider monitoring its service or affirmatively seeking facts indicating infringing activity, except to the extent consistent with a standard technical measure complying with the provisions of subsection (i); or

(2) a service provider gaining access to, removing, or disabling access to material in cases in which such conduct is prohibited by law.

Pertimbangan hakim dalam putusan kasus Viacom menyatakan bahwa Youtube terlindung oleh ketentuan safe harbor sehingga perbuatannya tidak dapat digolongkan sebagai pelanggaran hak cipta. Dengan adanya doktrin safe harbor keseimbangan beban kewajiban bagi penyelenggara sistem elektronik menjadi seimbang. Selain itu, doktrin safe harbor secara teknis mendukung pelindungan data privasi dan kekayaan intelektual tanpa perlu masuk ke pengadilan. Melalui notifikasi dan mekanisme menutup akses (suspend) konten negatif maka daya rusak dari konten negatif yang diunggah menjadi lebih kecil, dibandingkan dengan hanya bersandar pada norma RBF saja.

Berdasarkan penjelasan di atas, terlihat bahwa ada penggunaan konsep hak cipta pada perlindungan data pribadi di dunia siber yang diadopsi dalam perlindungan data pribadi. Di sini, prinsip moral secara tidak langsung dijadikan dasar untuk mengklaimnya. Prinsip moral yang berasal dari natural right merupakan prinsip yang tidak bisa dipandang sebagai prinsip sektoral yang hanya ada pada rezim hukum hak cipta saja. Dengan konstruksi prinsip moral yang mapan (established) pada hak cipta, maka pembentukan aturan tentang perlindungan data pribadi akan menjadi (robust). Argumentasi ini bisa digunakan untuk mengklaim hak kepemilikan atas data pribadi, yang mana hingga saat ini Indonesia belum memiliki Undang-Undang khusus tentnag perlindungan data pribadi. Berdasarkan argumentasi di atas, maka prinsip moral yang ada pada hak cipta bisa digunakan sebagai salah satu landasan untuk dijadikan klaim hak kepemilikan atas perlindungan data pribadi, yang mana hingga saat ini belum ada undang-undang yang secara khusus mengatur tentang data pribadi.

\section{Prinsip Moral pada Hak Cipta}


Prinsip moral pada hak cipta dikenal dengan hak moral seperti yang tercantum dalam pasal 6 bis Bern Convention 1928, rincian dari ketentuan ini adalah:

Independently of the author's economic rights, and even after the transfer of the said rights, the author shall have the right to claim authorship of the work and to object to any distortion, mutilation or other modifcation of, or other derogatory action in relation to, the said work, which would be prejudicial to his honor or reputation. (cetak tebal oleh penulis)

Ketentuan dalam Bern Convention mencakup hak untuk mengklaim ciptaan, hak untuk menolak: distorsi atas ciptaan, mutilasi, modifikasi ataupun derogasi yang mana keseluruhannya ditujukan untuk menghormati pencipta. Dari berbagai literatur tentang hak cipta, pembahasan tentang hak moral hampir sebagian besar tidak ada yang mendalam, bahkan di undang-undang hak cipta sendiri petunjuk tentang hak moral juga tidak diberi penjelasan. Ketiadaan pembahasan tentang hak moral, kemungkinan disebabkan karena tidak adanya sanksi tegas jika melanggar hak moral pada rezim hukum hak cipta, ${ }^{49}$ padahal seharusnya tidak demikian.

Prinsip HAM adalah landasan dari hak moral. Adapun konvensi internasional tentang HAM dapat ditemukan pada Universal Declaration on Human Right 1948.50 Ini menunjukkan bahwa hak moral merupakan hak yang kedudukannya melekat kuat pada diri seseorang, dalam hal ini adalah pencipta. Adapun doktrin hukum tentang hak moral antara lain:

Tabel 3. Doktrin Hukum tentang Hak Moral

\begin{tabular}{ll}
\multicolumn{1}{c}{ Doktrin } & \multicolumn{2}{c}{ Keterangan } \\
\hline $\begin{array}{l}\text { Droit de paternite atau } \\
\text { right of attribution }\end{array}$ & Yaitu menepatkan suatu ciptaan sebagai bagian yang tidak \\
& terpisahkan dari personalitas pencipta dalam setiap \\
& ciptaannya. Hak ini akan melekat selamanya dengan pencipta \\
& meskipun ciptaan tersebut sudah dialihkan kepemilikkannya \\
& pada pihak lain. Selain itu, meski perlindungan hak cipta sudah \\
& berakhir dan pencipta telah meninggal dunia hak personalitas \\
& dari pencipta tetap melekat pada ciptaannya. \\
\hline Droit de divulgation atau & Yaitu hak bagi pencipta untuk menentukan kapan dan \\
\hline
\end{tabular}

49 Lihat pasal 21 dan pasal 22 Undang-undang No. 28 Tahun 20142 tentang Hak Cipta yang mana mengatur tentang hak moral bagi pencipta.

50 Lihat pasal 27 ayat (2) Universal Declaration on Human Rights 1948. 


\begin{tabular}{ll}
\hline right of publication & bagaimana mempublikasikan sendiri ciptaannya kepada publik. \\
\hline $\begin{array}{l}\text { Droit de au respect de } \\
\text { l'integrite de l'oeuvre } \\
\text { atau right to respect of } \\
\text { the work }\end{array}$ & $\begin{array}{l}\text { Hak pencipta untuk menuntut dan mendapatkan ganti rugi } \\
\text { materil jika hak ciptanya dilanggar orang lain atau jika } \\
\text { ciptaannya diubah orang lain tanpa seijin pencipta }\end{array}$ \\
\hline $\begin{array}{l}\text { Droit de retrait et de } \\
\text { repentir atau right to } \\
\text { withdraw }\end{array}$ & $\begin{array}{l}\text { Hak pencipta untuk menarik ciptaannya dari publikasi dengan } \\
\text { berbagai alasan pribadi. Perlu diberi catatan bahwa hak ini } \\
\text { hanya diterapkan di negara Prancis, Jerman, Italia dan } \\
\text { Spanyol.51 }\end{array}$ \\
\hline
\end{tabular}

Dari doktrin hak moral tersebut di atas menurut Rigamonti ada keterkaitan antara hak moral dengan hak ekonomi. Keterkaitan antara hak moral dengan hak ekonomi adalah rights of disclosure dengan rights to withdrawal. ${ }^{52}$ Hak untuk menarik ciptaan (withdrawal) berhubungan langsung dengan hak ekonomi yaitu mengkomersialisasikan ciptaan sedangkan hak untuk membuka ciptaan (disclosure) berhubungan dengan tujuan pencipta untuk menjual hak ekonomi atas ciptaannya atau tidak menjualnya.

Rigamonti menjelaskan lebih lanjut bahwa kedudukan hak moral berada lebih tinggi dari hak ekonomi karena pencipta memiliki hak untuk menolak ciptaannya dimodifikasi meski hak ekonominya sudah dilepaskan kepada orang lain. Dasar tuntutan pencipta bagi pelanggar hak moral atas ciptaannya adalah ganti rugi, artinya jika merujuk pada hukum positif maka ketentuan ini dapat mengacu pada Burgelijke Wetboek (BW) dengan argumentasi perbuatan melawan hukum seperti yang dicontohkan Rigamonti pada hukum Perancis. Adapun batasan hak moral pada hak cipta adalah bagi hak cipta yang diciptakan secara bersama-sama karena pada jenis ciptaan tersebut kehilangan bentuk kepribadian dari penciptanya. ${ }^{3}$ Secara historis, pengaturan tentang hak moral yang diatur pada Undang-Undang Hak Cipta sejak tahun 1982 dapat ditunjukkan pada tabel di berikut ini.

51 Elyta Ras Ginting, Hukum Hak Cipta Indonesia, Analisis dan Teori, PT. Citra Aditya Bakti, Bandung, 2012, hlm., 91-92.

52 Cyrill P. Rigamonti, Deconstructing Moral Rights, Harvard International Law Journal, Vol. 47, Number 2. Summer 2006, hlm., 362.

53 Rigamonti menjelaskan pembatasan hak moral atau tidak berlakunya hak moral terhadap ciptaan yang dilakukan bersama-sama seperti program komputer seperti yang diatur oleh hukum Perancis dan hukum Jerman. Id., hlm., 364-365. 
Tabel 4. Doktrin Hak Moral pada Hukum Positif

\begin{tabular}{|c|c|}
\hline Hak Moral & $\begin{array}{l}\text { Undang-Undang Hak Cipta } \\
\end{array}$ \\
\hline $\begin{array}{l}\text { Droit de paternite atau right of } \\
\text { attribution }\end{array}$ & \multirow{2}{*}{$\begin{array}{l}\text { - Undang-undang No. } 28 \text { Tahun } 2014 \text { tentang Hak Cipta } \\
\text { - Undang-undang No. } 19 \text { Tahun } 2002 \text { tentang Hak Cipta } \\
\text { - Undang-undang No. } 12 \text { Tahun } 1997 \text { tentang } \\
\text { Perubahan atas Undang-undang Nomor } 6 \text { Tahun } 1982 \\
\text { tentang Hak Cipta Sebagaimana Telah Diubah Dengan } \\
\text { Undang-Undang Nomor } 7 \text { Tahun } 1987 \\
\text { - Undang-undang No. } 6 \text { Tahun } 1982 \text { tentang Hak Cipta } \\
\end{array}$} \\
\hline $\begin{array}{l}\text { Droit de paternite atau right of } \\
\text { attribution }\end{array}$ & \\
\hline $\begin{array}{l}\text { Droit de divulgation atau right } \\
\text { of publication }\end{array}$ & \multirow[t]{2}{*}{ Tidak diatur } \\
\hline $\begin{array}{l}\text { Droit de retrait et de repentir } \\
\text { atau right to withdraw }\end{array}$ & \\
\hline
\end{tabular}

Perkembangan hukum positif tentang hak cipta di Indonesia berdasarkan deskripsi tabel di atas terlihat jelas bahwa pembuat undang-undang tidak memasukkan prinsip moral secara utuh pada undang-undang hak cipta. Tidak dapat dipastikan apa penyebab dari hal ini apakah disengaja atau tidak. Padahal sebagaimana dijelaskan sebelumnya, keududukan hak moral lebih tinggi dibandingkan dengan keududukan hak ekonomi karena bersumber dari natural rights (hak alamiah). Jika merujuk pada ketentuan pada hukum hak cipta di Amerika Serikat yang mana ketentuan tentang hak moralnya adalah sebagai berikut:

(a) Rights of Attribution and Integrity. - Subject to section 107 and independent of the exclusive rights provided in section 106, the author of a work of visual art-

(1) shall have the right-

(A) to claim authorship of that work, and

(B) to prevent the use of his or her name as the author of any work of visual art which he or she did not create;

(2) shall have the right to prevent the use of his or her name as the author of the work of visual art in the event of a distortion, mutilation, or other modification of the work which would be prejudicial to his or her honor or reputation; and

(3) subject to the limitations set forth in section 113(d), shall have the right-

(A) to prevent any intentional distortion, mutilation, or other modification of that work which would be prejudicial to his or her honor or reputation, and any intentional distortion, mutilation, or modification of that work is a violation of that right, and

(B) to prevent any destruction of a work of recognized stature, and any intentional or grossly negligent destruction of that work is a violation of 


\section{that right.}

(b) Scope and Exercise of Rights.-

Only the author of a work of visual art has the rights conferred by subsection

(a) in that work, whether or not the author is the copyright owner. The authors of a joint work of visual art are coowners of the rights conferred by subsection (a) in that work.

(c) Exceptions.-

(1) The modification of a work of visual art which is a result of the passage of time or the inherent nature of the materials is not a distortion, mutilation, or other modification described in subsection (a)(3)(A).

(2) The modification of a work of visual art which is the result of conservation, or of the public presentation, including lighting and placement, of the work is not a destruction, distortion, mutilation, or other modification described in subsection (a) (3) unless the modification is caused by gross negligence.

(3) The rights described in paragraphs (1) and (2) of subsection (a) shall not apply to any reproduction, depiction, portrayal, or other use of a work in, upon, or in any connection with any item described in subparagraph (A) or (B) of the definition of "work of visual art" in section 101, and any such reproduction, depiction, portrayal, or other use of a work is not a destruction, distortion, mutilation, or other modification described in paragraph (3) of subsection (a). ${ }^{54}$

Ketentuan tentang hak moral yang diatur dalam Undang-Undang Amerika Serikat dikutip untuk mendeskripsikan bahwa pengaturan tentang hak moral di dalam keluarga sistem hukum non-civil law adalah hal yang dianggap langka dan menjadi perdebatan. Oleh karena itu ketentuan tentang hak atribusi dari prinsip moral baru dimasukkan ke dalam hukum positif Inggris pada tahun $1988 .{ }^{55} \mathrm{Hal}$ ini berbeda dengan negara dengan keluarga sistem hukum civil law seperti Perancis, dimana Undang-Undang hak ciptanya mengatur bahwa prinsip moral merupakan prinsip yang tertinggi.

Indonesia sebagai penganut sistem hukum civil law seharusnya mengadopsi ketentuan tentang hak moral pada hukum hak ciptanya. Hal ini menjadi penting untuk melindungi pencipta untuk menikmati manfaat ekonomi dari karya ciptaannya. Pelanggaran moral pada pencipta seringkali terjadi, misalnya pada kasus Bimbo yang perjanjian pembayaran royalti atas lagunya dimonopoli oleh

54 Undang-Undang Hak Cipta Amerika Serikat diundangkan pada tahun 1947, (bagian) secsion 106A adalah amandemen dari Undang-Undang hak cipta Amerika pada tahun 1997 yang dikenal dengan sebutan 'Visual Artist Right Act/VARA act, 1997.

55 William Cornish, David Llewelyn, Tanya Aplin, Intellectual Property: Patents, Copyrights, Trademarks Allied Rights, Sweet Maxwell Ltd. UK. 2013, hlm., 514. 
produser dengan ikatan perjanjian, artinya di sini menunjukkan bahwa kekuatan mengikat suatu perjanjian begitu kuatnya sehingga menabrak hak alamiah dari pencipta. Kuatnya ikatan perjanjian dalam doktrin hukum perdata seolah-olah menutup pintu masuk pencipta untuk mempertahankan haknya. Padahal landasan fundamental untuk mempertahankan hak moral adalah hak asasi manusia yang tentunya tidak dapat dikesampingkan oleh hukum kontrak. ${ }^{56}$

Tabel 5. Prinsip Moral pada Undang-Undang No. 28 Tahun 2014 tentang Hak Cipta

\begin{tabular}{|c|c|}
\hline Pemegang Hak & Prinsip Moral \\
\hline $\begin{array}{l}\text { Hak Cipta } \\
\text { (hak moral melekat } \\
\text { abadi pada pencipta) }\end{array}$ & $\begin{array}{l}\text { Pasal } 5 \text { ayat (1): } \\
\text { Hak moral sebagaimana dimaksud dalam pasal } 4 \text { merupakan hak yang } \\
\text { melekat secara abadi pada diri pencipta untuk: } \\
\text { a. Tetap mencantumkan atau tidak mencantumkan namanya pada } \\
\text { salinan sehubungan dengan pemakaian ciptaannya untuk umum; } \\
\text { b. Menggunakan nama alias atau samarannya; } \\
\text { c. Mengubah ciptaannya sesuai dengan kepatutan dalam masyarakat; } \\
\text { d. Mengubah judul dan anak judul ciptaan; dan } \\
\text { e. Mempertahankan haknya dalam hal terjadi distorsi ciptaan, mutilasi } \\
\text { ciptaa, modifikasi ciptaan, atau hal yang bersifat merugikan } \\
\text { kehormatan diri atau reputasinya. }\end{array}$ \\
\hline $\begin{array}{l}\text { Pelaku pertunjukan } \\
\text { (hak moral melekat } \\
\text { pada pelaku } \\
\text { pertunjukkan yang } \\
\text { tidak dapat dihilangkan } \\
\text { atau tidak dapat } \\
\text { dihapus dengan alasan } \\
\text { apapun walaupun hak } \\
\text { ekonominya telah } \\
\text { dialihkan) }\end{array}$ & $\begin{array}{l}\text { Pasal 22: } \\
\text { Hak moral pelaku pertunjukan sebagaimana dimaksud dalam pasal } 21 \\
\text { meliputi hak untuk: } \\
\text { a. Namanya dicantumkan sebagai pelaku pertunjukan, kecuali } \\
\text { disetujui sebaliknya; dan } \\
\text { b. Tidak dilakukannya distorsi ciptaan, mutilasi ciptaan, modifikasi } \\
\text { ciptaan, atau hal-hal yang bersifat merugikan kehormatan diri atau } \\
\text { reputasinya kecuali disetujui sebaliknya }\end{array}$ \\
\hline
\end{tabular}

Dari deskripsi tabel di atas terlihat bahwa hak moral hanya ada pada pencipta dan pelaku pertunjukkan. Hak moral tidak dimiliki oleh produser fonogram dan lembaga penyiaran karena pada mereka alas hak yang dapat dimiliki adalah hak ekonomi saja. Dalam kaitannya dengan praktik pengalihan hak ekonomi, cara jual putus atau sold-flat adalah perjanjian yang merugikan pencipta yang sering kali terjadi. Oleh karena itu pembuat Undang-undang No. 28 Tahun 2014 tentang Hak Cipta berusaha menjawab masalah ini dengan memuat ketentuan bahwa pengalihan tanpa batas waktu/jual putus/sold-flat hak ciptanya

56 Imas Rosidawati \& Edy Santoso, Pelanggaran Hak Moral Atas Karya Cipta Dalam Penerbitan Elektronik, http://e-journal.kopertis4.or.id/file/PELANGGARAN\%20HAK\%20MORAL.pdf, diakses Agustus 2015. 
akan kembali kepada penciptanya setelah 25 tahun sebagaimana diatur pada pasal 18 Undang-Undang Hak Cipta.

Terkait penghapusan praktik jual putus/sold-flat pada hak cipta, sepertinya pembuat ragu-ragu untuk menghapuskannya karena tidak secara tegas dilarang, tetapi dikompromikan dengan mewajibkan untuk mengembalikan hak ekonomi kepada pencipta setelah 25 tahun. Dalam perspektif hak moral ketentuan pasal 18 ini justru mengesampingkan ketentuan pasal 5 yang mengatur bahwa hak moral adalah hak yang melekat secara abadi kepada pencipta. Seharusnya, pembuat Undang-Undang berani dan tegas melarang pengalihan hak ekonomi tanpa batas waktu. Hal ini setidaknya memiliki tiga alasan.

- Pertama, Indonesia sebagai negara penganut sistem hukum civil law maka secara nature harus melindungi hak naluriah (hak moral) warga negaranya,

- Kedua, pelanggaran hak moral dapat dikategorikan sebagai perbuatan melawan hukum, yang mana di dalam ketentuan pasal 1320 BW adanya pelanggaran di syarat obyektif dari perjanjian. Maka dengan demikian perjanjian pengalihan hak ekonomi tanpa batas waktu menjadi batal demi hukum. ${ }^{57}$

- Ketiga, perlindungan hukum bagi pencipta adalah hal yang mutlak karena karya cipta dihasilkan oleh pencipta bukan dihasilkan dari industri hak cipta.

Dari ketiga alasan hukum di atas maka dapat dikatakan bahwa perlindungan hak pencipta adalah suatu keniscayaan untuk memotivasi pencipta untuk selalu kreatif dan berkarya. Pengaturan tentang prinsip moral yang didapat dari doktrin dan aturan hukum negara-negara lain jika dikorespondensikan ke dalam UndangUndang No. 28 Tahun 2014 tentang Hak Cipta yang tidak diatur adalah: (1) resale right, (2) right to withdraw, dan (3) right of publication. Dari tiga prinsip moral yang tidak diatur, apabila melihat negara yang mengatur prinsip moral seperti di Jerman dan Perancis maka dapat ditentukan prinsip-prinsip umumnya adalah sebagai berikut.

57 Meski demikian ketentuan tentang cakupan perjanjian pengalihan hak dan pelanggaran dari bentuk hak moral perlu dicermati secara mendalam. 
Tabel 6. Prinsip Umum Hak Moral di Perancis dan Jerman

\begin{tabular}{|c|c|}
\hline Hak Moral & Prinsip Umum \\
\hline $\begin{array}{l}\text { Resale right } \\
\text { (hak mendapat } \\
\text { royalti dari penjualan } \\
\text { hak cipta) }\end{array}$ & $\begin{array}{l}\text { 1. Ahli waris dapat menikmati manfaat ekonomi; } \\
\text { 2. Jangka waktu menikmati manfaat ekonomi oleh ahli waris adalah } \\
70 \text { tahun setelah pencipta meninggal; } \\
\text { 3. Permohonan yang diajukan oleh ahli waris harus mendapat } \\
\text { persetujuan menteri; } \\
\text { 4. Royalti yang bisa didapat oleh ahli waris adalah } 24 \text { jam setelah } \\
\text { penjualan, kecuali diperjanjikan lain; } \\
\text { 5. Adanya nilai minimal penjualan untuk mendapatkan royalti (resale } \\
\text { right), yaitu 100 Euro. }\end{array}$ \\
\hline $\begin{array}{l}\text { Right to withdraw } \\
\text { (hak menarik } \\
\text { ciptaan) }\end{array}$ & $\begin{array}{l}\text { 1. Pencipta berhak mendapat manfaat ekonomi selama masa } \\
\text { hidupnya; } \\
\text { 2. Ahli waris dari pencipta berhak mendapat manfaat ekonomi dengan } \\
\text { jangka waktu } 70 \text { tahun sejak pencipta meninggal; } \\
\text { 3. Cara-cara publikasi sebuah hak cipta tidak boleh dicantumkan di } \\
\text { dalam perjanjian, harus diserahkan sepenuhnya pada pencipta } \\
\text { 4. Penarikan suatu hak cipta harus mendapat persetujuan menteri } \\
\text { 5. Penarikan hak cipta harus diumumkan ke dalam berita acara hak } \\
\text { cipta }\end{array}$ \\
\hline $\begin{array}{l}\text { Right of publication } \\
\text { (hak menarik ciptaan } \\
\text { jika tidak sesuai } \\
\text { dengan cara yang } \\
\text { ditentukan oleh } \\
\text { pencipta) }\end{array}$ & $\begin{array}{l}\text { 1. Pencipta memiliki hak menarik ciptaannya jika dirasa ciptaannya } \\
\text { diubah oleh orang lain yang merusak kehormatan dan reputasinya } \\
\text { 2. Penarikan ciptaan dengan tidak sesuainya cara publikasi dengan } \\
\text { yang diinginkan oleh pencipta harus melalui putusan pengadilan. }\end{array}$ \\
\hline
\end{tabular}

Dari prinsip-prinsip umum tentang pengaturan hak moral yang diatur di Perancis dan Jerman terlihat sangat jelas bahwa Undang-Undang hak cipta mereka sangat berpihak pada pencipta. Perlindungan yang kuat terhadap pencipta merupakan ciri khas dari aturan hak cipta di negara penganut sistem hukum civil law. Indonesia sebagai penganut sistem hukum civil law seharusnya dapat menerapkan hal ini dengan memasukkan prinsip-prinsip umum tersebut di atas. Hal ini menjadi penting mengingat tujuan utama dari pembentukkan UndangUndang hak cipta tahun 2014 adalah memperkuat perlindungan bagi pencipta, tetapi kenyataannya ketentuan norma hukumnya tidak demikian.

\section{Penutup}

Natural right adalah sumber utama dari prinsip perlindungan hak pribadi dan data pribadi sebagai subsetnya. Dalam perspektif hak cipta, natural right ini diturunkan menjadi prinsip moral dan menjadi hak hukum barupa hak moral. Dari dua bidang hukum di atas, prinsip moral lebih mapan (established) ada pada rezim 
hukum hak cipta karena ditetapkan pasca konvensi Bern 1928. Pada hak cipta, prinsip moral merupakan prinsip yang berasal dari negara penganut sistem hukum Eropa Kontinental, sedangkan prinsip ekonomi berasal dari negara penganut sistem hukum Anglo-Saxon. Oleh sebab itu, konvensi Bern 1982 bisa dikatakan sebagai konsensus antar negara-negara peserta untuk menggabungkan prinsip moral dan prinsip ekonomi.

Di era digital saat ini, kebutuhan akan perlindungan data menjadi penting untuk diantisipasi. Melalui prinsip moral yang sudah mapan diterapkan pada hak cipta maka prinsip ini bisa diterapkan untuk melindungi data pribadi. Selain itu, perlindungan data pribadi juga berkembang sehingga memunculkan hak baru yang dikenal dengan sebutan hak untuk dilupakan (right to be forgotten). Penerapan hak untuk dilupakan ini perlu diimbangi dengan adanya doktrin safe harbor, yang mana kedua ketentuan di atas ditujukan kepada penyelenggara sistem elektronik. Melalui pembebanan kewajiban untuk membuat mekanisme untuk menjaga konten positif (diantaranya konten yang bebas dari pelanggaran hak cipta dan data pribadi orang lain) maka mekanisme ini dapat mengurangi daya rusak konten negatif yang diunggah di internet. Dengan cara ini maka efektivitas aturan hukum dapat tercapai.

\section{Daftar Pustaka}

\section{Buku}

Adilah Abd. Razak, Understanding Legal Research, 20. Integration and Dissemination, Universiti Putra Malaysia, 2009.

Alfred C. Yen, Internet Service Provider Liability for Subscriber Copyright Infringement, Enterprise Liability, and the First Amendment, The Georgetown Law Journal, Vol. 88. 2000.

Alessandro Mantelero, The EU Proposal for a General Data Protection Regulation and the roots of the 'right to be forgotten', Computer Law \& Security Review, vol. 29 (3) 2013.

Bambang Pratama, ICT Law Framework Toward ASEAN Economy Community, Unisbank Semarang, 2013.

Betsy Rosenblatt, Moral Rights Basic, Harvard Law School, March 1998, https://cyber.law.harvard. edu/property/library/moralprimer.html, diakses: Agustus 2015 
Clare McAndrew \& Lorna Dallas-Conte, Implementing Droit de Suite (Artist' Resale Right) in England, The Art Council of England, 2014.

Cyrill P. Rigamonti, Deconstructing Moral Rights, Harvard International Law Journal, Vol. 47, Number 2. Summer 2006.

Cyrill P. Rigamonti, The Conceptual Transformation of Moral Rights, The American Journal of Comparative Law, Vol. 55. 2007.

Daniel J. Solove. Conceptualizing Privacy. California Law Review, 2002.

Elyta Ras Ginting, Hukum Hak Cipta Indonesia, Analisis dan Teori, PT. Citra Aditya Bakti, Bandung, 2012.

Ernest Miller and Joan Feigenbaum, Taking The Copy Out of Copyright, http://www.cs.yale.edu/ homes/jf/MF.pdf, diakses November 2016.

Gerald Gaus. Property and Ownership, Edited by: David Estlund, Oxford University Press, 2012.

Haochen Sun, Designing Journeys to the Social World: Hegel's Theory of Property and His Noble Dream Revisited, Cosmos and History: The Journal of Natural and Social Philosophy. Vol. 6. No. 1, 2010.

Henry Desbois, Le Droit d'Auter En France, (1978). Dalam Mira T. Sundara Rajan, Moral Rights: Principles, Practice and New Technology, Oxford University Press, New York, USA, 2011.

http://sisni.bsn.go.id/index.php?/sni_main/sni/detail_sni/10233, diakses November 2016.

http://www.assemblee-nationale.fr/12/cri/2005-2006/20060175.asp, diakses Agustus 2015.

Imas Rosidawati \& Edy Santoso, Pelanggaran Hak Moral Atas Karya Cipta Dalam Penerbitan Elektronik, http://e-journal.kopertis4.or.id/file/PELANGGARAN \%20HAK\%20MORAL.pdf, diakses Agustus 2015.

Jan Gijssels \& Mark van Hoecke. Wat is rechtsteorie? (1982). Diterjemahkan oleh B. Arief Sidharta. (2001). Apakah Teori Hukum Itu? 34. (Laboratorium Hukum, Fakultas Hukum, Universitas Katolik Parahyangan, 2001).

Jon. L. Mills. Privacy The Lost Right. 14. (Oxford University Press. New York, 2008).

Kanu Priya, Intellectual Property and Hegelian Justification, NUJS Law Review, 2008.

Michael B. Reddy, The Droit de Suite: Why American Fine Artist Should Have a Right to a Resale Royalty, 509-510, Layola Marymount University and Loyola Law School. 1995.

Paul Goldstein, International Copyright, Principle. Law, and Practice, Oxford University Press, Madison Avenue, New York, 2001.

Prue Vines, The Sacred and the Profane: The Role of Property Concepts in Disputes about Post-mortem Examination, Sydney Law Review, Vol. 29:235.

Rebecca Tushnet, Naming Rights: Attribution \& Law, Utah Law Review, 2007.

Richard A. Epstein. Property Right, State of Nature Theory, and Environmental Protection, Journal of Law and Liberty. New York University. 2009.

Richard A. Epstein. The 'Necessary' History of Property and Liberty, University of Chicago. 2003.

Richard A. Epstein. The Path to The T.J. Hooper: The Theory and History of Custom in The Law of Torts, Chicago Law Review. 1991. 
Robert A. Brunette, Rehabilitation, Privacy and Freedom of the Press, Loyola of Los Angeles Law Review, 1972.

Robert C. Post, Three Concepts of Privacy. 2088, Faculty Scholarship Series. Paper 185. Yale Law School, 2001.

Soerjono Soekanto, Pengantar Penelitian Hukum, UI-Press, 1984.

Soetandyo Wignjosoebroto, Penelitian Hukum dan Hakikatnya Sebagai Penelitian Ilmiah, dalam Metode Penelitian Hukum Konstelasi dan Refleksi, Editor: Sulistyowati Irianto \& Shidarta, Yayasan Obor, Jakarta, 2011.

Sri Soedewi Masjchoen Sofwan, Hukum Perdata: Hukum Benda, Liberty Yogyakarta, Cetakan kelima, 2000.

Suzanna Sherry. Property is The New Privacy, The Coming Constitutional Revolution. Harvard Law Review. 2015.

Thomas F. Cotter, Pragmatism, Economics, and The Droit Moral, North Carolina Law Review, November 1997, http://cyber.law.harvard.edu/metaschool /fisher/integrity/Links/Articles/ cotter.html, diakses: Agustus 2015.

William Cornish, David Llewelyn, Tanya Aplin, Intellectual Property: Patents, Copyrights, Trademarks Allied Rights, Sweet Maxwell Ltd. UK. 2013.

\section{Sumber Hukum}

A \& M Records v. Napster pada tahun 2001.

Kitab Undang-Undang Hukum Pidana

Melvin vs. reid, 112 Cal.App. 285 (Cal.Ct. App. 1931)

Metro-Goldwyn-Mayer Studio Inc. v. Grokster LTD. Pada tahun 2003.

Peraturan Pemerintah No. 82 Tahun 2012 tentang Penyelenggara Sistem dan Transaksi Elektronik

Peraturan Presiden No. 44 Tahun 2015 tentang Kementerian Hukum dan Hak Asasi Manusia.

Putusan MA Nomor 305/K/PDT.SUS-HKI/2014.

Religious Technology Center v. Netcom On-Line Communication Services, Inc. pada tahun 1995.

Undang-undang Hak Cipta Jerman, Die Übersetzung berücksichtigt die Änderung(en) des Gesetzes durch Artikel 8 des Gesetzes vom 1.10.2013 (BGBl. I S. 3714)

Undang-undang hak cipta Perancis, L122-12, Code la propriété intellectuelle (partie législative, partie réglementaire)

Undang-undang No. 11 Tahun 2008 tentang Informasi dan Transaksi Elektronik

Undang-undang No. 28 Tahun 20142 tentang Hak Cipta

Universal Declaration on Human Rights 1948.

Viacom International Inc. v. Youtube Inc. \& Google. 2013.

Visual Artist Right Act/VARA act, 1997. 